Irina V. Leskova

\title{
Social Mechanisms of Harmonization of the Rela- tions between Muslim and Christian Culture ${ }^{1}$ \\ Družbeni mehanizmi harmonizacije odnosov med muslimansko in krščansko kulturo
}

Abstract: The article is devoted to the theoretical and methodological problems of the study of relations between Muslim and Christian culture. It has been shown that the globalization processes in the world affect all spheres of human life, diversifies it, promotes interpenetration of cultures, increases pluralism, and requires a new vision of the world in all its manifestations. It has been actualized that in today's world traditions related to religious ones mostly gain the form of religious culture. The new state of secular culture and the emerging socio-cultural environment is accompanied by the activation of religious structures, institutions and processes, which are called »desecularization «, "religious renaissance" and "revitalization of religion « in the scientific literature. The dialogue between Islam and Christianity, Muslim and Christian culture, has historical and religious roots. In the era of wide development of Islamic culture, Muslims actively contributed to the establishment of mutual understanding with other people and civilizations. History shows that Islam has been the initiator of dialogue and exchange of opinions with other cultures for ages. The Holy Scripture of Muslims, The Koran, in many verses obliges its followers to conduct an intellectual dialogue with members of other religions. The unique and centuries-old experience of religious interaction on the territory of Russia strives at maintaining the religious identity by Christians and Muslims alike. Dialogue within the Cristian and Islamic culture in Russia does not provide for and even prevent attempts for selection of dogmatic integrity and unity of religious knowledge, however it implies the need of individual, personal relationships and joint solutions of various socio-cultural problems and challenges, where the tasks of the spiritual and moral development of society are the most important ones.

Keywords: Muslim and Christian cultures, social mechanisms, harmonization of relations, Koran, Bible, religious renaissance

1 The article has been prepared under the Research work of the RSSU 2018 Social mechanisms of harmonization of relations between Muslim and Christian cultures. 
Poværetek: Članek je posvečen teoretičnim in metodološkim problemom pri preučevanju odnosov med muslimansko in krščansko kulturo. Različni avtorji ugotavljajo, da globalizacijski procesi v svetu vplivajo na vsa področja človekovega življenja, ga delajo bolj raznolikega in spodbujajo medsebojno prežemanje kultur, povečujejo pluralizem in zahtevajo nov pogled na svet v vseh njegovih pojavnostih. Vse bolj aktualna je tudi ugotovitev, da v današnjem svetu tista izročila, ki so povezana z izročili te ali one religije, navadno dobivajo obliko religiozne kulture. Novo stanje sekularne kulture in vzpostavljajočega se družbeno-kulturnega okolja spremlja vse večja dejavnost religijskih struktur, institucij in procesov, ki jo v znanstveni literaturi imenujejo »desekularizacija«, »religiozni preporod « in »revitalizacija religije«. Dialog med islamom in krščanstvom, med muslimansko in krščansko kulturo, ima svoje zgodovinske in religiozne korenine. $V$ času širokega razmaha islamske kulture muslimani dejavno prispevajo k vzpostavljanju medsebojnega razumevanja z drugimi ljudmi in civilizacijami. Zgodovina nam kaže, da je bil islam že globoko v preteklosti pobudnik dialoga in izmenjave mnenj z drugimi kulturami. Koran, sveta knjiga muslimanov, $v$ številnih odlomkih svoje privržence obvezuje $k$ stopanju v intelektualni dialog s pripadniki drugih religij. Edinstvena in več stoletij trajajoča izkušnja stikov med različnimi religijami na ozemlju Rusije spodbuja k ohranjanju religijske identitete tako pri kristjanih kakor tudi pri muslimanih. Dialog med krščansko in islamsko kulturo v Rusiji ne omogoča in celo preprečuje poskuse krhanja dogmatične zaokroženosti in enovitosti religijskega znanja oz. nauka, a vseeno predvideva potrebno po individualnem, osebnem odnosu in skupnih rešitvah različnih družbeno-kulturnih problemov in izzivov, pri čemer se naloge duhovnega in moralnega razvoja družbe kažejo kot najpomembnejše.

Ključne besede: muslimanska in krščanska kultura, družbeni mehanizmi, harmonizacija odnosov, Koran, Biblija, religiozni preporod

\section{Introduction}

The subject of this article is quite rational. Our time features with globalization, which is characterized not only by the return of many peoples to an active role in history, but also by the revision of the importance of their cultures in the world history. Many cultures are based on certain religions, so the meaning of religion for the revival of certain cultures needs to be revised. The historical reality itself sets the task of clarifying the importance of religion for the people and for culture as a whole, as well as to clarify the meaning of religious culture. Religion has always played an important role in the functioning of human society: the self-identification functions, life ritualization, social integration, perception of the world, communication, etc. All these functions become especially actual today, at the time of great sociocultural changes and postmodern ideas, which dispute the traditional values. There is even a scientific position stating that people unite 
around traditional sources of identity, ethnic and religious one, in the world with chaotic and uncontrolled processes of social changes. The famous scholar-medievalist U. Eco called that trend »the return to the New Middle Ages" $(1994,258-$ 267). Moreover, the issues of preserving traditional Christian and Muslim identity are extremely important under the global development of terrorism, since it is the identity that has formed historically, preserving cultural national codes, which can serve as a basis for modelling the inter-confessional consent policy and be the guarantor of religious stability.

On the other hand, the new geopolitical vision and globalization processes have created such conditions that do not allow living in separate civilizations, with state and canonical frontiers. The world has become a crossroad of all religions, where a new meeting of Christianity and Islam takes place. Today, $33 \%$ of the world's population professes the Christian religion, almost $23 \%$ - Islamic. By the middle of this century, the number of Muslims and Christians can become equal.

The interaction of civilizations is an indispensable condition, causing the perception of values of other cultures. Interaction and mutual interaction are complex and contradictory process, causing different changes. According to P. A. Sorokin, "such an interaction, no matter how painful it may be, is a necessary condition for any culture to be creatively developed throughout its existence. The creativeness of any culture can be exhausted, and then the cultures and societies become sdead and uncreativer. Cultures and societies that do not change form and do not find new ways and means of transferring values become inert and unproductive." $(1992,433)$. V. M. Mezhuyev has similar thoughts, believing that »it is difficult to confine oneself only to the past in modern conditions. Many things have to be rethought, created, or borrowed from other nations. Otherwise the culture is only a historical relic, to be placed in the museum, not in life." $(2001,569)$

World religions of general human orientation contain a reflection of the national life of a certain ethnos. The religion reproduces certain characteristics inherent in the culture, way of life, customs, and traditions. Therefore, it acts as a specific form of both uniting and alienating people of one ethnic nationality, but of different confessions.

Russian social and human sciences have significant achievements in the study of Islam and Christianity, the conceptual foundations of peaceful coexistence, the legal traditions of the two world religions and many tangential themes. However, the Christian-Muslim dialogue, as a dialogue between Christian and Muslim cultures, has not yet become the subject of systematic sociological comprehension (Fawaz 2016, 365-382). However, the study of the past, present and prospects of this dialogue is not only a matter of theoretical interest. The fate of the two worId religions, Christian and Muslim cultures, and humanity depends on this dialogue (Shihab 2004, 65-77; Haddad and Smith 2009, 369-388).

Russia is also interested in developing such a dialogue, as evidenced by numerous attempts to start the relevant discussions. Today, both religious scholars and theologians do not have enough strength to go beyond general statements about 
the peaceful nature of the two religions, the positive experience of coexistence, the need for deepening practical cooperation. A fundamental scientific task of great importance is identifying the conceptual foundations of the Christian-Muslim dialogue, Christian and Muslim cultures, which is the true potential of the openness of the modern theology of the two world religions (Smith 1987, 18-21).

The analysis of the problem of the Christian-Muslim dialogue is primarily connected with clarifying the essence and content of such concepts as "religious culture», "Muslim culture", "Christian culture» (Leskova 2009, 81-83).

The religious culture means a special sphere of culture, where the content and targeting of actions by all the subjects is directed to comprehension the complexities of metaphysical nature of human existence, the society, and the world as a whole, which are based on irrational dogmas. The most important component of the religious culture is considered to be worshipping. There is a material (based on a religious cult) and spiritual religious culture. The religious basis becomes the core of the national culture, the uniqueness of which depends on the features of the world vision and interpretation. The achievements of scientific progress do their part in the religious culture. Gradually, a new attitude to the world around, a new type of religious culture, which uses the new human cognitive abilities in turning to God, is formed. The current state of religious culture reflects the relationship between culture and religion, where the experience of a future culture, including Russian society, is implicitly embedded. There are both internal factors of religious culture development and transformation - they are the internal logic of the development of religion itself (modernization, reforms within some religious faiths) - and external ones, such as social and political processes, the development of information technologies. Against the background of modern transformations of religious culture, new information technologies that have the function of communicative and informational enrichment of culture acquire special relevance among external factors that influence public consciousness (politics, ideology, science) through the establishment and reproduction of connection between human and Godly realm, between the clergy and coreligionists.

In its most general form, Christian culture is a special order of a society based on Christian worship and worldview. The Muslim culture in the narrow sense can be represented as the culture of Muslim nations, following and preserving the orthodox Islamic values and customs. In a broad sense, it can be interpreted as the classical and modern culture of all peoples professing Islam and living on the territory of its coverage. (Islamic Encyclopedia)

\section{Experimental}

The problem of relations between the Christian and Muslim cultures cannot be solved without a method or methodological guidelines, and the issue of methodological and theoretical grounds opens the prospect of introducing methods of 
interdisciplinary sciences widely used today in the philosophy of religion, anthropology, history, sociology, political science. In this regard, the socio-cultural and civilizational approaches are promising.

The socio-cultural approach to the study of the socio-religious sphere includes several key characteristics that point to its integration potential and, at the same time, can serve as arguments in favor of the expediency of its application in the studies of the above-mentioned sphere. First, a socio-cultural approach focuses on the existence and integral characteristics of the supra-organic world and, therefore, requires an understanding of the society and culture as a whole. The unity of the social and cultural gives rises to characterize this world as a socio-cultural reality and its phenomena as socio-cultural phenomena. The sociocultural approach also presupposes an understanding of culture and sociality as interpenetrating fragments of reality. It is actualized in the conditions of modernization and secularization, when religion is increasingly moving beyond the range of religious ideas and appears as a "multitude» of cultural meanings, values, and senses. A religious community (in the Islamic culture - umma) can be considered as such an example of the cultural form that represents the way of being of an individual in the realities of modern society. In addition, it is important to pay attention to the fact that, from the standpoint of the sociocultural approach, society, culture and the individual need to be considered as a complex indivisible unity. The culture itself in this case appears as representative, which encompasses beliefs, beliefs, worldviews and ideologies that people either perceive actively or recognize passively. (Leskova and Zyazin 2018, 62-69)

As for the civilizational approach, it is used not only as a comparative method for studying the specifics of the development of various civilizations with their particular cultural values. It has shown the unjustified aggressiveness of the anthropocentric approach to history, which levelled the development of the high culture of other non-Western civilizations. The importance of the civilizational approach includes "refusal of the Eurocentrism principle, which is a narrow approach to the world history analysis, a consequence of the lack of knowledge about the history of other peoples, and a certain demonstration of superiority over other, non-Western civilizations" (Islamic Encyclopedia).

The civilizational approach makes analysis of the historical chronology of the whole humanity's development possible as a multivariate and alternative process, denying the course of development as a united vector of historical development of civilization, empirically represented by the history of Western Europe. This approach promotes the identification of both unique and universal-cultural values, as well as the specificity of the cultural values of certain civilizations. Regarding the attitude to the religious culture, the thought of E. Durkheim that, in fact, there is no religion that would be completely erroneous, is methodologically important. All of them are correct in their own way; all of them, although in different ways, correspond to these conditions of human existence. (Krasnikov 1998, 174-177) 


\section{Results}

Starting from the second half of the 20th century, the term "dialogue» is used in the context of intercultural and interreligious relations. For example, the documents of the Second Vatican Council (1962-1965), the adopted Declaration on the relation of the Church to non-Christian religions Nostra aetate especially underline the fact that the Church wexhorts her sons, that through dialogue and collaboration with the followers of other religions, carried out with prudence and love /... / they recognize, preserve and promote the good things, spiritual and moral, as well as the socio-cultural values found among these men " (NA 1965).

Analyzing the semantics of the "dialogue concept, V. E. Manapova notes that its meaning is close to the "discourse" concept, "however, the traditions of using these terms differ. The important distinguishing markers between them are the fact, that sdialoguer emphasizes the interactive nature of language use, whereas the use of the sdiscourser concept requires inclusion of communication in the social context« $(2013,21)$.

Development of the ontological basis of the dialogue belongs to "dialogism" (represented by M. Buber, M. Bakhtin, F. Ebner, E. Rosenstock-Huessy, etc.). Earlier, the dialogue was only a form for storing other meanings, because the idea of a dialogue was inconspicuous for those who were in its form.

We should note that the modern dialogue of cultures is not only a religious dialogue. A religious dialogue is a theological dialogue. In this sense, the Muslim-Christian theological dialogue arose, developed, and achieved significant progress in recent decades, mainly in the form of polemics. This, however, does not prevent the theologians, who represent these religions, from finding common values, seeking ways to move from the ethics of theological tolerance to the positions of broad-based worldview solidarity. The Muslim-Christian theological dialogue meets many challenges, as the processes of globalization contributed not only to the constructive relationships between civilizations and religions, but also caused a fundamentalist reaction in the form of Islamism and anti-Islamic motives in modern Christian eschatological futurology. Under the growing threats to the future civilization, the identification of the positive potential for the further development of the Muslim-Christian theological dialogue is of particular importance. In general, the researchers distinguish three levels of the existing Christian-Muslim dialogue (Waardenburg 1999). The first level is actually a modern dialogue between theologians who are Christians and Muslims. Jacques Waardenburg thinks the Muslim Christian Research Group to be the most important. Fifteen scientists at the initiative of Father G. Kaspar established it in 1977. It includes the representatives of Islam, Catholicism, and Protestantism who are widely known for their theological and historical researches. This initiative is being supported and developed with the help of the Roman Pontifical Institute for Arabic and Islamic Studies, the Center for Christianity and Islam Studies at the University of Birmingham, the Center for Muslim-Christian Understanding (Georgetown University, Washington, DC) and the Paris Institute for the Arab and Islamic Studies. The second level 
of the dialogue is practical. It includes a broader cooperation of Muslims and Christians in Western and Muslim countries for ensuring human rights, protection of minorities, peaceful resolution of conflicts, and looking for ways to achieve justice and peace. The third level of the dialogue concerns the studies that change the Eastern view of the West and the Western view of the East. The discovery of the cultural heritage of the "others " does not allow us to see the "other " as barbarians, but opens the way from alienation and conflicts to tolerance. The first level of dialogue is of greatest importance today. However, all three levels of dialogue were of great importance in the Middle Ages as well, as stereotypes about the "other " were formed at that time, which have not been overcome in full till present. The third level of dialogue had a significant impact on Christian and Muslim theological discussions, meant to deconstruct stereotyped ideas rooted in scientific discourse in the times of modernity and postmodernity.

\section{Discussion}

A dialogue between Christian and Muslim cultures predetermines the existence of certain common principles and life goals between parties thereof. A. M. Al-Rauhani says: "The dialogue of cultures must be based on two fundamental principles: recognition of the existence of the sother as its attributive right; understanding of the sother ' as a necessary cultural component. The understanding of the sother implies understanding of one people by another - the mental, cultural, scientific, and religious component, studying the economic and social situation for easier detection of parallels, where we should conduct the dialogue of cultures." (Manapova 2013, 21)

As we can see, "the other (discourser) is fundamentally important for the dialogue. Religion is the subject of the interreligious dialogue. Another religion plays the role of the "other «. The main initial condition (the essence of such a dialogue), according to the classical model of dialogue, should be the recognition of the "other " - any religion can potentially be a discourser in a dialogue, equal in rights in the model of »interreligious dialogue " under such conditions. Therefore, the initial condition for interreligious dialogue is the perception of another religion as an equal to the own. If we apply this principle to the inter-religious dialogue, the other religion cannot be alien in the dialogue mechanism, but duly becomes the own in the course of the dialogue and interaction. Now a question arises: Can any religion conduct an interreligious dialogue, defining another religion equal to its own, recognizing its doctrines to be equal to its own? The sacred texts of world religions call for equal treatment of the "others". That is, each religion is potentially ready to recognize the other as equal, based on the sacred texts. We emphasize that the sacred texts are not a unique source for the religions to rely when presenting the position as of the other religions. We can find an answer in the official position of a certain religion, provided for in the official materials, documents, social doctrines (if any) in relation to the other religions. For example, the 
Christian religion recognizes the »others" as "heathens" or "heretics", "sectarians", and Islam separates between Muslims, "the people of the Book", and »infidels«. We emphasize a clear separation in »ours" and »others". The presented distribution of the other religions recognizes their "alienation «. It is obvious that this is far from treating the "other" as an equal, based on which a relationship of parity can be built. That is why the Christian and Muslim dialogue must not discuss the content of faith of each party.

\section{Conclusion}

One of the directions for solving the problem is the construction of a Christian and Islamic dialogue on the principles of commonality of meaningful values: this means exclusion of dogmatic or orthodox-religious disputes that are not constructive and, as history shows, fundamentally unable to reach consensus, as they are not about the truths of the mind, but about the truths of faith.

On the level of equal Orthodox-Islamic dialogue, the missionary activity of the parties aimed at proselyting the opponent should be prohibited. We should also note that, as a rule, the Orthodox side has never fallen back on missionary activity among Muslims. The Catholics and Protestants acted the other way, even now they are actively engaged in missionary work, in Islamic countries as well, but their missions always "had the only result: an outburst of Muslim wrath, the victim of which were not only visiting preachers with a handful of proselytes, but also local Christian communities. Orthodox and Muslims never had a clash anywhere on religious grounds precisely because Orthodoxy always respected the main condition for good-neighborliness with Islam: non-interference in its internal affairs." (Ikim 2018) These particular characteristics and the quality of Orthodoxy and Islam, as a commitment to traditions based on respect for their own history and culture, and maintaining high standards for the moral standards of believers - they may become, in our opinion, the common ground enabling a constructive Orthodox-Islamic dialogue.

\section{References}

Eco, Umberto. 1994. Srednie veka uzhe nachalis? [The Middle Ages has already begun?]. Inostrannaya literature 4:258-267 (in Russ.)

Fawaz, Ahmed Abdel-Hafez. 2016. The Muslims in Russia: between historical legacy and contemporary problematics. Journal Contemporary Arab Affairs 9, №. 3:365-382.

Haddad, Yvonne Yazbeck, and Jane I. Smith. 2009. The Quest for 'A Common Word': Initial Christian Responses to a Muslim Initiative. Journal Islam and Christian-Muslim Relations 20, No. 4:369-388.
Ikim, Vladimir, Archbishop. S.a. Tashkent and Central Asia. Printsipy pravoslavno-islamskogo dialoga [Principles of the Orthodox-Islamic Dialogue]. http://www.mission-center.com/ islams/vladimir.htm (accessed 20.01.2018).

Islamic Encyclopedia. S.a. Musulmanskaya kultura [Muslim culture]. http://islamist.ru/ (accessed 20.01.2018).

Krasnikov, Alexandr, ed. 1998. Klassiki mirovogo religiovedeniya [Classics of World Religious Studies]. Moskow: Canon+Publ. (in Russ.) 
Leskova, Irina. 2009. Globalization as a factor in the transformation of social identity. In: Russian Society in Sociological Dimension collected works of USR to the $9^{\text {th }}$ ESA conference in Lisbon, 81-83. Union of sociologists of Russia.

Leskova, Irina, and Sergey Zyazin. 2018. Muslim and Christian cultures: social mechanisms of harmonization of relations. Journal of Social policy and sociology 17, No.1:62-69 (in Russ.).

Manapova, Violetta. 2013. Reprezentatsiya etnicheskogo samosoznaniya v mezhkul'turnom dialoge (filosofsko-kul'turologicheskiy analiz) [Representation of ethnic self-awareness in intercultural dialogue (philosophical and cultural analysis)], Doctoral Thesis. SPBU, Makhachkala (in Russ.)

Mezhuyev, Vadim. 2001. Kultura kak predmet filosofskogo znaniya [Culture how the subject philosophical knowledge]. Moskow: Prospekt Press Publ. (in Russ.)

NA - Second Ecumenical Vatican Council. 1965. Declaration on the relation of the church to non-christian religions Nostra aetate.
Shihab, Alwi. 2004. Christian-Muslim relations into the twenty-first century. Journal Islam and Christian-Muslim Relations 15, No.1:65-77.

Smith, Wilfred Cantvell. 1987. Muslim-Christian relations: questions of a comparative religionist. Journal Institute of Muslim Minority Affairs 8, No.1:18-21.

Sorokin, Pitirim. 1992. Chelovek. Tsivilizatsiya. Obshchestvo [Human. Civilization. Society]. Moskow. (in Russ.)

Waardenburg, Jacques. 1999. Muslim Perceptions of Other Religions. New York - Oxford: Oxford University Press. 